\title{
Anticonvulsant activity of alcoholic root extract of Cardiospermum halicacabum
}

\section{Daniel Dhayabaran, ${ }^{I}$ Jeyaseeli Florance, ${ }^{1}$ Nandakumar Krsihnadas, ${ }^{, 2}$ Indumathi, ${ }^{3}$ Muralidhar ${ }^{3}$}

${ }^{1}$ Farooqia College of Pharmacy, Mysore, Karnataka, India,

${ }^{2}$ Department of Pharmacology, Manipal College of Pharmaceutical Sciences, India,

${ }^{3}$ Department of Pharmacology, PES Institute of Medical Sciences and Research, Kuppam, Andhra Pradesh, India.

\begin{abstract}
The aim of the present study was to evaluate the anticonvulsant effects of alcoholic root extract of Cardiospermum halicacabum L., Sapindaceae (ARECH), on the various murine models of epilepsy. The root extract of the plant was administered p.o. to male swiss albino mice at doses of 30,100 and $300 \mathrm{mg} / \mathrm{kg}$ before evaluation. The brain monoamine levels were determined after two days administration. ARECH at doses of 100 and $300 \mathrm{mg} / \mathrm{kg}$ significantly delayed the onset of clonus and tonus in pentylenetetrazol, isoniazid and picrotoxin-induced convulsions. Tonic hind limb extension was also decreased at doses of 100 and $300 \mathrm{mg} / \mathrm{kg}$ as compared to vehicle control in maximal electroshock model. No significant motor toxicity was observed even at a highest dose administered, i.e. $900 \mathrm{mg} / \mathrm{kg}$. Brain monoamine analysis by HPLC revealed a significant increase in GABAergic activity in $\mathrm{C}+$ (in cerebellum) and $\mathrm{C}$ - (except cerebellum). These results suggested that $\mathrm{ARECH}$ possesses a significant anticonvulsant activity with a low motor toxicity profile. This activity may be attributed to an increase in GABAergic activity.
\end{abstract}

Revista Brasileira de Farmacognosia Brazilian Journal of Pharmacognosy 22(3): 623-629, May/Jun. 2012

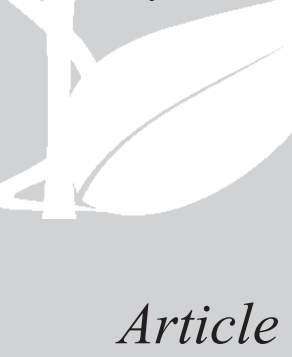

Received 3 Aug 2011

Accepted 22 Oct 2011

Available online 24 Jan 2012

Keywords:

Cardiospermum halicacabum,

GABA

maximal electroshock induced seizures pentylenetetrazol picrotoxin

ISSN 0102-695X http://dx.doi.org/10.1590/S0102 $695 \times 2012005000017$

\section{Introduction}

Epilepsy is a common neurological disorder affecting an estimated 40-50 million people worldwide (Rudiger, 2002). The incidence of epilepsy is highest among children below 7 years-of-age and in individuals of above 55 years. The prevalence of epilepsy in India has been reported to be about 5.5 to 7.9 per 1,000 people, which is approximately about $1 / 18^{\text {th }}$ of the world population (Nag, 2000). Anticonvulsant drugs (ACD) are the most commonly prescribed drugs for epilepsy and seizure disorders due to their high efficacy in the treatment of these disorders (Liow et al., 2007). Many of the existent ACD produce a host of undesirable sideeffects including teratogenesis, drowsiness, mental dullness, nausea, ataxia, paresthesia, hematologic changes, hirsutism, weight gain, hypertrophy of gums and congenital malformations. For these reasons, new ACD are needed to improve seizure control and reduce the side-effect profile (Gasior et al., 1997).

The Ayurvedic system of medicine has a quite sophistical classification of medicinal plants as per the dominant pharmacological/therapeutic activity of mental functions (Vaidhya, 1997). Ethnopharmacological approaches have provided leads to identify potential new drugs from plant sources, including targets for neuronal disorders (Howes \& Houghton, 2003).

Cardiospermum halicacabum L., commonly known as 'Kanphuti', from family Sapindaceae, is an annual or perennial climber, widely distributed in tropical and subtropical Asia and Africa, and often found throughout India (Sheeba \& Asha, 2009). The whole plant has been used for several centuries in the treatment of rheumatism, stiffness of limbs and snake bite whereas the root alone has been used for curing diseases related to the nervous system (Muthu et al., 2006; Subramanyam et al., 2007). The root is mucilaginous and considered emetic, laxative and anti-rheumatic and the seeds are used as a tonic for fevers and as a diaphoretic (Joshi et al., 1992). Traditional Indian folklore describes the use of root for the treatment of anxiety and epilepsy (Venkteshbabu \& Krishnakumari, 2006).

This study has been undertaken to investigate the pharmacological basis for the use of the alcoholic root extract of Cardiospermum halicacabum and to understand the mechanisms following its anticonvulsant activity.

\section{Material and Methods}

\section{Chemicals}


The drugs used were diazepam (DZ) (Ranbaxy Lab. Ltd., Thane), phenytoin (Zydus Neuroscience, Ahemedabad) and isoniazid (Radicura Pharmaceuticals, New Delhi). Picrotoxin, strychnine and pentylenetetrazol (PTZ) were purchased from Sigma Aldrich, USA. Other chemicals used for extraction and phytochemical investigation were of analytical grade from S.D. Fine Chemicals, Mumbai, India.

\section{Plant material}

Whole plant of Cardiospermum halicacabum L., Sapindaceae, was collected from the villages in and around Kuppam in Chittoor district in the Indian state of Andhra Pradesh during the month of July, 2007. The plant material was authenticated by Dr. K. Lakshman, Professor and Head, Department of Pharmacognosy, P.E.S. College of Pharmacy, Bangalore and a specimen was preserved for future reference, bearing voucher number CIP-01 at the same institute. The plants were uprooted, roots collected, washed thoroughly to remove the debris, dried in shade and powdered. The powder was subjected for extraction using different polarities of solvents in a soxhlet apparatus.

\section{Preparation of extracts of Cardiospermum halicacabum}

About $200 \mathrm{~g}$ of the root powder of $C$. halicacabum was successively extracted. Extraction with petroleum ether was carried out at $60-80{ }^{\circ} \mathrm{C}$ for $72 \mathrm{~h}$ using soxhlet apparatus. The dried marc obtained after petroleum ether extraction was subjected to further extraction with $95 \%$ alcohol. The aqueous extract was prepared by maceration for $72 \mathrm{~h}$ with distilled water containing chloroform $(0.25 \% \mathrm{v} / \mathrm{v})$ as preservative. All the extracts obtained were concentrated and dried by vacuum distillation till the solvents were completely removed. The percentage yield of ARECH was reported to be 11.9 .

\section{Preliminary phytochemical investigations}

The ARECH was subjected to preliminary qualitative investigations (Khandelwal, 2007).

\section{Animal care}

Adult male Wistar rats (160-180 g) and male Swiss albino mice (18-22 g) were selected. Animals were housed under an alternative $12 \mathrm{~h}$ light/dark cycle in polypropylene cages with softwoud granulate bedding. Three animals were housed in a single cage. Pelleted food and water were made available ad libitum. Animals used in these studies were maintained in facilities fully accredited by the CPCSEA and all experiments were performed under protocols approved by the Institutional Animal Ethics Committee (PES IMSR/Pharma/ IAEC/002).

\section{Acute toxicity}

The LD50 value of ARECH was determined by using female, nulliparous and non pregnant mice weighing 18-22 g. The animals were fasted for $3 \mathrm{~h}$ prior to the experiment. Animals were administered with single dose of extract and observed for its mortality during 48 h (short term toxicity). Different doses of the extracts were administered to different animals based on the short term toxicity till the stop criteria was met as per OECD guideline 425 . LD50 was calculated by using AOT 425 software provided by Environmental Protection Agency, USA (OECD, 2001).

\section{Anticonvulsant tests}

Maximal electroshock induced seizures (MES)

Tonic convulsions of the hind extremities of male mice were induced by passing alternating electrical current $(50 \mathrm{~Hz}, 60 \mathrm{~mA}, 0.2 \mathrm{~s})$ through ear clip electrodes by a Rodent shocker generator (Inco Electroconvulsometer model\# 100-3). For each experiment, one group served as the control ( $3 \%$ tween $80,10 \mathrm{~mL} / \mathrm{kg}$, p.o.) and one group as the standard (Phenytoin, $25 \mathrm{mg} / \mathrm{kg}$, p.o.). The test extract, ARECH was also administered at various doses $(30,100$ and $300 \mathrm{mg} / \mathrm{kg}$, p.o.). The number of animals protected from tonic hind limb extension seizure and the latency of onset were determined in each dose group. Percentage protection against mortality was also calculated (Wamil et al., 1994).

\section{PTZ Seizure test}

Convulsions were induced in male mice by injecting PTZ ( $80 \mathrm{mg} / \mathrm{kg}$, i.p.). The time of onset of clonic and tonic convulsions was noted. ARECH was tested at various doses $(30,100$ and $300 \mathrm{mg} / \mathrm{kg}$, p.o.) along with vehicle control ( $3 \%$ tween $80,10 \mathrm{~mL} / \mathrm{kg}$, p.o.) and a standard, DZ (10 mg/kg, p.o.) (Nassiri Asi et al., 2009).

\section{Picrotoxin (PT) induced seizures}

PT (3.5 mg/kg, i.p.) was injected $(\mathrm{n}=6)$ in male mice, pre-treated $60 \mathrm{~min}$ prior with varying p.o. doses of ARECH $(30,100$ and $300 \mathrm{mg} / \mathrm{kg})$, vehicle (3\% tween 80 , $10 \mathrm{ml} / \mathrm{kg}$, p.o.) and diazepam $10 \mathrm{mg} / \mathrm{kg}$ (standard group). Latency to clonic and tonic convulsions was noted in all groups. All the extract treated groups were compared with control in order to determine the significant anticonvulsant activity (Leewanich et al., 1996). 


\section{Strychnine induced convulsions}

Male mice were randomly allotted to the different control and test groups. Convulsions were induced in male mice by the i.p. injection of $3.5 \mathrm{mg} / \mathrm{kg}$ strychnine (STN). Graded doses $(30,100$ or $300 \mathrm{mg} / \mathrm{kg}$, p.o.) of ARECH were given to the test groups $60 \mathrm{~min}$ before strychnine. The latency of onset of tonic extensor convulsions was recorded (Adeyemi et al., 2007).

\section{Isoniazid induced convulsions}

Male mice were injected with isoniazid (INH), $300 \mathrm{mg} / \mathrm{kg}$, i.p. one hour after the administration of the ARECH. The time of onset of clonic or tonic seizures was recorded (Bernasconi et al., 1988). Data of the control group ( $3 \%$ tween $80,10 \mathrm{~mL} / \mathrm{kg}$, and p.o.) were compared to data of the group treated with the ARECH. The standard group received DZ, $10 \mathrm{mg} / \mathrm{kg}$, p.o.

\section{Motor toxicity test}

Pre-trained male mice were subjected to rota rod test after $1 \mathrm{~h}$ administration of the control ( $3 \%$ tween 80 , $10 \mathrm{~mL} / \mathrm{kg}$, and p.o.), standard (DZ, $10 \mathrm{mg} / \mathrm{kg}$, and p.o.) or ARECH treatment (30, 100, 300, 600 and $900 \mathrm{mg} /$ $\mathrm{kg}$ ). The time taken for the animals to fall off from the rota rod was recorded in seconds. Inability to stay on the rota rod for less than 1 minute was considered as motor impairment (Sun et al., 2006).

\section{Determination of brain monoamine and $G A B A$}

Adult male Wistar rats weighing 160-180 g were treated with the test or standard drug and control group was treated with equimolar quantity of saline for two days. Rats were sacrificed by decapitation $1 \mathrm{~h}$ after treatment of last dose and heads were dropped in ice cold $0.1 \mathrm{M}$ perchloric acid. Immediately the brain was removed, weighed and homogenized in $2 \mathrm{~mL}$ of $0.1 \mathrm{M}$ perchloric acid. After centrifugation at $14000 \mathrm{x}$ for $15 \mathrm{~min}$ at $4{ }^{\circ} \mathrm{C}$, the supernatant was filtered through $0.45 \mu \mathrm{m}$ membrane and $100 \mu \mathrm{L}$ of the filtrate was injected into HPLC column. After separation, noradrenaline (NE), dopamine (DA), serotonin (5HT) and GABA were detected at the excitation wavelength of $280 \mathrm{~nm}$ and emission wavelength $350 \mathrm{~nm}$. The mobile phase used for the determination, consisted of sodium acetate $(0.02 \mathrm{M})$, methanol $(16 \%)$, heptane sulphonic acid (0.055\%), EDTA (0.2 mM) and dibutyl amine $(0.01 \% \mathrm{v} / \mathrm{v})$. The solution was adjusted to $\mathrm{pH} 3.92$ with orthophosphoric acid and filtered through $0.45 \mu \mathrm{m}$ membrane (Madepalli et al., 1997). Brain GABA level was estimated using paper chromatography as described by Maynert et al, 1962.

\section{Statistical analysis}

Assessment of the acute oral toxicity and their LD50 values (convulsant drugs) with 95\% confidence limits was calculated using a computerized version of the AOT 425 software provided by Environment Protection Agency, USA. The latency of onset of clonictonic convulsions and duration of hind limb extensions values were expressed as mean \pm SEM from six animals. Statistical differences in means were calculated using one way ANOVA followed by Dunnett's post hoc test using GraphPad Prism 5.02 software.

\section{Results}

\section{Phytochemical investigations}

ARECH was found to contain fixed oils, fats, proteins, flavonoids, phenolics and tannins, carbohydrates, saponins, phytosterols and triterpenoids.

\section{Acute oral toxicity}

ARECH, when administered to mice at dose level of $550 \mathrm{mg} / \mathrm{kg}$, showed no mortality. However at $2000 \mathrm{mg} / \mathrm{kg}, 67 \%$ of the animals died. The LD50 was found to be $1098 \mathrm{mg} / \mathrm{kg}$, probably suggesting that the plant's extract is relatively safe in mice.

Table 1. Effect of alcoholic root extract of Cardiospermum halicacabum on maximal electroshock induced seizures induced convulsions.

\begin{tabular}{ccccc}
\hline Treatement & $\begin{array}{c}\text { Duration of tonic } \\
\text { flexion (s) }\end{array}$ & $\begin{array}{c}\text { Duration of tonic } \\
\text { extension (s) }\end{array}$ & $\begin{array}{c}\text { Latency onset of } \\
\text { clonus (s) }\end{array}$ & $\begin{array}{c}\text { Percentage protection } \\
\text { against mortality }\end{array}$ \\
\hline Control (3\% tween 80$)$ & 0 & $15.66 \pm 1.14$ & $3 \pm 0.57$ & 0 \\
Phenytoin $(25 \mathrm{mg} / \mathrm{kg})$ & $6.16 \pm 1.07^{* *}$ & 0 & $15.17 \pm 0.94^{* *}$ & 100 \\
ARECH $30 \mathrm{mg} / \mathrm{kg}$ & 0 & $11.5 \pm 1.17$ & $4.16 \pm 0.60$ & 0 \\
ARECH $100 \mathrm{mg} / \mathrm{kg}$ & 0 & $7.34 \pm 0.67^{* *}$ & $10.17 \pm 0.98^{*}$ & 34 \\
ARECH 300 mg/kg & 0 & $6.17 \pm 0.47^{* *}$ & $9.67 \pm 1.05^{*}$ & 50 \\
\hline
\end{tabular}

Values are expressed as mean \pm SEM from six mice. Significant at $* p<0.05$ and $* * p<0.01$ as compared to control group. One way ANOVA followed by Dunnett's multiple comparison post hoc test. 
Table 2. Effect of alcoholic root extract of Cardiospermum halicacabum on PTZ induced convulsions.

\begin{tabular}{lccc}
\hline \multicolumn{1}{c}{ Treatment } & Onset of clonus in $\mathrm{s}$ & Onset of tonus in s & Percentage protection against mortality \\
\hline Control $(3 \%$ tween 80$)$ & $46.33 \pm 1.67$ & $138.16 \pm 12.19$ & $0 \%$ \\
Diazepam $10 \mathrm{mg} / \mathrm{kg}$ & 0 & 0 & $100 \%$ \\
ARECH $30 \mathrm{mg} / \mathrm{kg}$ & $88.16 \pm 6.12^{*}$ & $303.25 \pm 13.56^{* *}$ & 0 \\
ARECH $100 \mathrm{mg} / \mathrm{kg}$ & $167.5 \pm 16.42^{* *}$ & $477.2 \pm 15.08^{* *}$ & $17 \%$ \\
ARECH $300 \mathrm{mg} / \mathrm{kg}$ & $210.16 \pm 13.04^{* *}$ & $654.4 \pm 32.69^{* *}$ & $17 \%$ \\
\hline
\end{tabular}

Values are expressed as mean \pm SEM from six mice. Significant at $* p<0.05$ and $* * p<0.01$ as compared to control group. One way ANOVA followed by Dunnett's multiple comparison post hoc test.

Table 3. Effect of ARECH on picrotoxin induced convulsions.

\begin{tabular}{lccc}
\hline \multicolumn{1}{c}{ Treatment } & Onset of clonus in s & Onset of tonus in s & Percentage protection against mortality \\
\hline Control (3\% tween 80) & $284.16 \pm 14.57$ & $559.83 \pm 41.68$ & 0 \\
Diazepam $10 \mathrm{mg} / \mathrm{kg}$ & $593.5 \pm 50.74^{*}$ & $1226 \pm 80.11^{*}$ & 34 \\
ARECH $30 \mathrm{mg} / \mathrm{kg}$ & $330.5 \pm 47.04$ & $620.9 \pm 101.74$ & 0 \\
ARECH $100 \mathrm{mg} / \mathrm{kg}$ & $355.2 \pm 15.43$ & $781.56 \pm 22.70$ & 17 \\
ARECH $300 \mathrm{mg} / \mathrm{kg}$ & $566.3 \pm 31.65^{*}$ & $1137.4 \pm 35.50^{*}$ & 17 \\
\hline
\end{tabular}

Values are expressed as mean \pm SEM from 6 mice. Significant at $p<0.05^{*}$ as compared to control group. One way ANOVA followed by Dunnett's multiple comparison post hoc test.

Table 4. Effect of ARECH on strychnine induced convulsions.

\begin{tabular}{lcc}
\hline \multicolumn{1}{c}{ Treatment } & Onset of tonus in s & Percentage protection against mortality \\
\hline Control $(3 \%$ tween 80$)$ & $155 \pm 16.07$ & 0 \\
Diazepam $10 \mathrm{mg} / \mathrm{kg}$ & $147.66 \pm 16.73$ & 0 \\
ARECH $30 \mathrm{mg} / \mathrm{kg}$ & $190.66 \pm 22.46$ & 0 \\
ARECH $100 \mathrm{mg} / \mathrm{kg}$ & $220 \pm 11.10^{*}$ & 0 \\
ARECH $300 \mathrm{mg} / \mathrm{kg}$ & $216 \pm 17.31$ & 0 \\
\hline
\end{tabular}

Values are expressed as mean \pm SEM from 6 mice. Significant at $p<0.05^{*}$ as compared to control group. One way ANOVA followed by Dunnett's multiple comparison post hoc test.

\section{Effect of ARECH on MES induced seizures}

ARECH exhibited dose dependent reduction in duration of tonic extension, tonic flexion and latency of onset of clonus compared to vehicle control. Doses of 100 and $300 \mathrm{mg} / \mathrm{kg}$ showed similar effect, while percentage protection against mortality was higher at $300 \mathrm{mg} / \mathrm{kg}$ dose level (Table-1).

\section{Effect of ARECH on PTZ induced seizures}

PTZ $(80 \mathrm{mg} / \mathrm{kg}$, i.p. $)$ induced clonic and tonic convulsions in all the groups. The onset of clonic convulsions in control animals was $46.33 \pm 1.67 \mathrm{~s}$ while onset of tonic convulsions in the same animal was $138.16 \pm 12.19$ s. ARECH $(30,100$ and $300 \mathrm{mg} / \mathrm{kg}$, p.o. $)$ produced $[(p<0.05),(p<0.01)]$ significant increase in the duration of onset of tonic-clonic convulsions in a dose dependent manner (Table 2). The reference anticonvulsant drug used, DZ, $10 \mathrm{mg} / \mathrm{kg}$, p.o. protected all the animals from PTZ-induced clonic convulsions.

\section{Effect of ARECH on PT-induced convulsions}

Pre-treatment with ARECH at dose $300 \mathrm{mg} /$ $\mathrm{kg}$ produced a significant increase in duration of onset of tonic-clonic convulsions $(p<0.01)$. The reference anticonvulsant, DZ (10 $\mathrm{mg} / \mathrm{kg}$, p.o. $)$, also increased the latency of tonic-clonic convulsions $(p<0.01)$ compared to vehicle control (Table 3 ).

\section{Effect of ARECH on STN-induced convulsions}

Only at a dose of $100 \mathrm{mg} / \mathrm{kg}$, ARECH significantly $(p<0.05)$ produced prolongation of onset of tonic convulsion. None of the animals were protected from seizures or from death. Both diazepam and ARECH were ineffective in STN-induced convulsions (Table 4).

\section{Effect of ARECH on INH-induced convulsions}

In the case of INH-induced convulsions, ARECH $300 \mathrm{mg} / \mathrm{kg}$ delayed the onset of clonic and 
tonic convulsions as compared to control. However DZ $(10 \mathrm{mg} / \mathrm{kg}$, p.o. $)$ exhibited significant effect $(p<0.01)$ in clonic and $(p<0.05)$ tonic convulsions induced by INH (Figure 1).

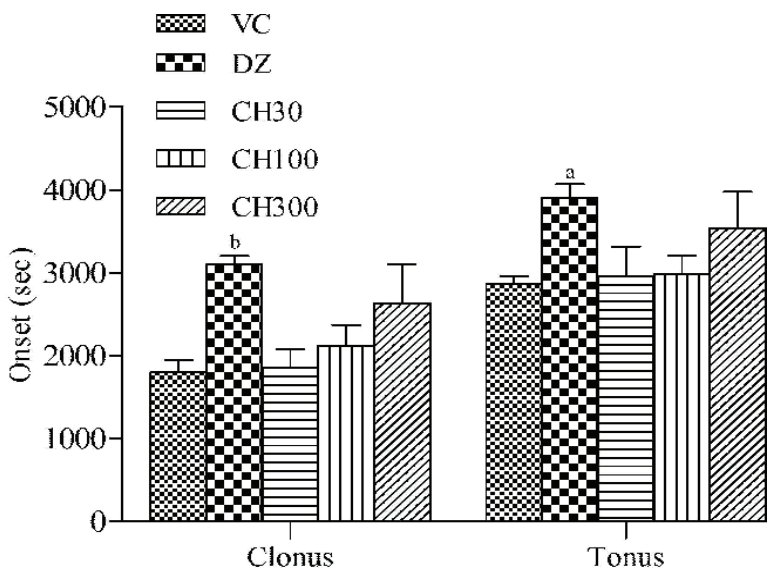

Figure 1. Effect of alcoholic root extract of Cardiospermum halicacabum on INH induced convulsions. Values are mean \pm SEM; $n=6$. Analysed by one way ANOVA followed by Dunnet's post hoc test at ${ }^{\mathrm{a}} p<0.05$ and ${ }^{\mathrm{b}} p<0.01$, as compared to VC.

\section{Motor toxicity of ARECH}

ARECH produced a dose-dependent decrease in time spent on the rota rod. However at all doses (100, 300,600 and $900 \mathrm{mg} / \mathrm{kg}$ ), the animals were able to walk on the rota rod for more than 1 min thus did not affect motor coordination in mice (Figure 2).

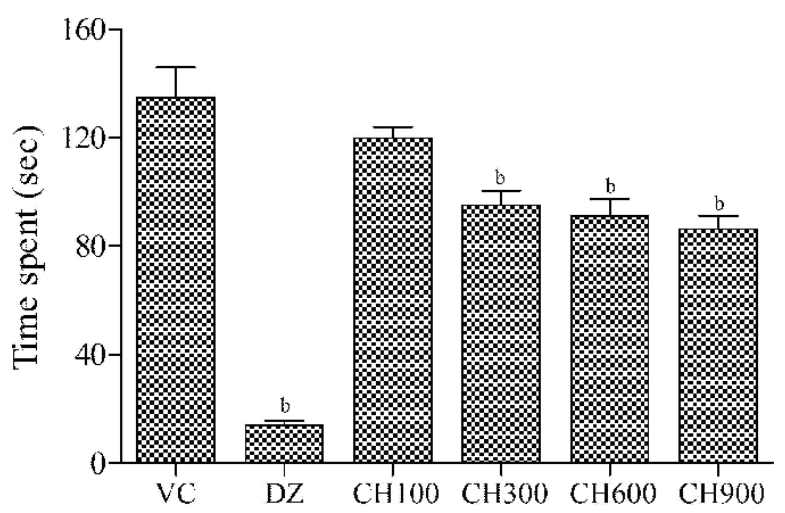

Figure 2. Effect of different concentration of alcoholic root extract of Cardiospermum halicacabum on motor toxicity. Values are expressed as mean \pm SEM; $n=6$. ${ }^{\mathrm{b}} p<0.01$, in comparison to VC. One way ANOVA followed by Dunnett's multiple comparison post hoc test.

\section{Effect of ARECH on brain monoamine levels}

The ARECH (100 and $200 \mathrm{mg} / \mathrm{kg}$ ) significantly enhanced the GABA activity in cerebellum $(\mathrm{C}+)$ as well as except cerebellum (C-) when compared to control $(p<0.05)$. However, there is no significant difference observed in other monoamine levels (5 HT, NE and DA) [Figure 3 and 4].

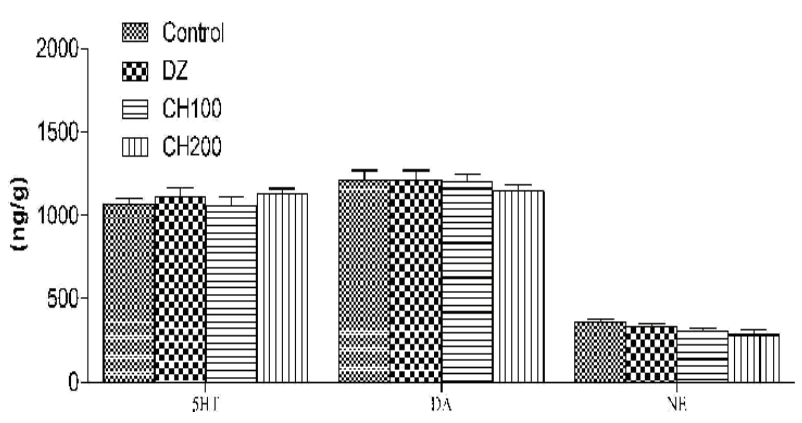

Figure 3. Effect of alcoholic root extract of Cardiospermum halicacabum on brain monoamine levels [5-HT, DA, NE]. One way ANOVA followed by Dunnett's multiple comparison post hoc test showed no significance observed in monoamine levels as compared to $\mathrm{VC}$.

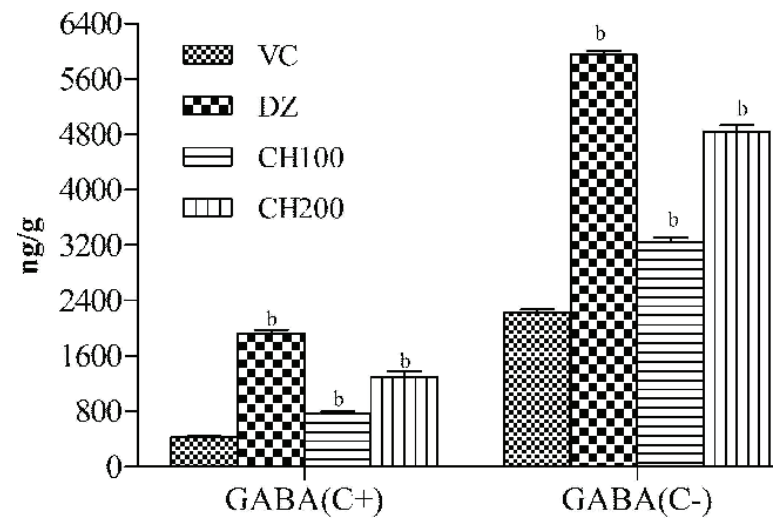

Figure 4. Effect of alcoholic root extract of Cardiospermum halicacabum on brain GABA levels [GABA C+ (in cerebellum) and GABA C-(except cerebellum)]. ${ }^{\mathrm{b}} p<0.01$, in comparison to VC. One way ANOVA followed by Dunnett's multiple comparison post hoc test.

\section{Discussion}

In the present study, our results demonstrate the anticonvulsant action of ARECH by using classical models for screening of ACD. The spectrum of its anticonvulsant activity was characterized further by performing various seizure models in comparison to the standard anticonvulsants. Protection against hind limb tonic extension in MES test predicted the ability of ARECH to prevent the spread of seizure discharge from the epileptic foci in brain. In addition, the effectiveness in MES test can be correlated with efficacy of drugs that suppress generalised tonic-clonic and partial seizures by causing use dependent blockage of voltage-sensitive sodium channels and by enhancing GABAergic mediated 
neurotransmission (Krall et al., 1978; Loscher \& Schmidt, 1988).

The activity of ARECH in PTZ test indicated the presence of anticonvulsant compounds that may produce an effect either by inhibiting low threshold T-type $\mathrm{Ca}^{2+}$ currents or by enhancing GABAA receptor mediated inhibition, as PTZ-induced seizures can be blocked by standard drugs that reduce T-type $\mathrm{Ca}^{2+}$ currents, such as ethosuximide, and drugs that enhance GABAA receptor mediated inhibition, such as benzodiazepines, phenobarbital and valproic acid (White, 1999; Sun et al., 2009). BZ, receptors may be primarily involved in the convulsant action of PTZ (Griebel et al., 1999). Hence, there may be a possible predominant involvement of $\alpha_{2}$-containing GABAA receptors in the convulsant action of PTZ. GABAA receptors (primarily those containing $\alpha_{1}$ and $\alpha_{2}$ subunits), may explain the potency of ARECH against tonic rather than against myoclonic and clonic seizures as well as a dose-dependent difference in the potency of ARECH against different PTZ-induced seizures (Dhir et al., 2006).

In this work, ARECH offered protection to mice against PT-induced seizures. There was a significant $(p<0.05)$ increase in seizure threshold with higher doses of the extract. PT, a pro-convulsant drug blocks chloride channel directly (Anthony \& Walter., 1998). Thus the pathway of activity of the extract can be through GABA receptor activation. STN directly antagonizes the inhibitory spinal reflexes of glycine (Chen et al., 2007). ARECH did not exhibit its anticonvulsant effect on STN-induced convulsions thus indicating its glycine independent activity. INH is regarded as an inhibitor of GABA synthesis,thus produces the convulsion. ARECH $300 \mathrm{mg} / \mathrm{kg}$ delayed the onset of clonic and tonic convulsions as compared to control which may be due to the inhibition of the INH induced clonic-tonic convulsions indicating its GABA potentiating activity (Vogels, 2008). In addition, the analysis of monoamine levels in the brain has provided additional evidence for its GABA mediated activity.

Impaired locomotor activity and coordination are known problems with barbiturates and benzodiazepines, and are among the factors influencing poor compliance (Mattson, 1992). ARECH did not affect motor coordination in animals closer to its LD50 value. However further studies required to assess the therapeutic window of ARECH related to psychomotor dysfunction.

\section{Conclusion}

In conclusion, the present data indicates that ARECH is active in multiple seizure models, and may be efficient against both grandmal and partial seizures, as it prevents seizure spread by inhibiting the tonic seizure activity in well-established animal seizure models. ARECH has an acceptable safety profile as evidenced by acute toxicity and acute neurotoxicity tests. Although the exact mechanism of action of ARECH needs more investigation, the overall effect of ARECH in seizure models indicates that it mediates a part of its effect through GABA mediated neurotransmission.

\section{Acknowledgement}

The authors wish to thanks the Manipal University and PES Institute of Medical Sciences and Research, Kuppam for their support and facilities for this work. The authors also express thanks to Dr. K. Lakshman for authenticating the plant.

\section{References}

Adeyemi OO, Yemitan OK, Adebiyi OO 2007. Sedative and anticonvulsant activities of the aqueous root extract of Sanseviera liberica Gerome and Labroy (Agavaceae). $J$ Ethnopharmacol 113: 111-114.

Anthony JT, Walter LW 1998. Sedative-hypnotic drugs. In: Betram GK (ed) Basic and Clinical Pharmacology, $9^{\text {th }}$ ed, Appleton and Lange, p. 351-365.

Bernasconi R, Klein M, Martin P, Christen P, Hafner T, Portet C 1988. Gamma-vinyl GABA: comparison of neurochemical and anticonvulsant effects in mice. $J$ Neural Transm 72: 213-233.

Chen LW, Wang YQ, Wei LC, Shi M, Chan YS 2007. Chinese herbs and herbal extracts for neuroprotection of dopaminergic neurons and potential therapeutic treatment of Parkinson's disease. CNS Neurol Disord Drug Targets 6: 273-281.

Dhir A, Naidu PS, Kulkarni SK 2006. Effect of cyclooxygenase inhibitors on pentylenetetrazol (PTZ)-induced convulsions: possible mechanism of action. Prog Neuropsychopharmacol Biol Psychiatry 30: 14781485.

Gasior M, Carter RB, Goldberg SR, Witkin JM 1997. Anticonvulsant and behavioural effects of neuroactive steroids alone and in conjunction with Diazepam. $J$ Pharm Exp Ther 282: 543-553.

Griebel G, Perrault G, Letang V, Granger P, Avenet P, Schoemaker H 1999. New evidence that the pharmacological effects of benzodiazepine receptor ligands can be associated with activities at different BZ $(\omega)$ receptor subtypes. Psychopharmacology 146: 205-213.

Howes MJ, Houghton PJ 2003. Plants used in Chinese and Indian traditional medicine for improvement of memory and cognitive function. Pharmacol Biochem Behav 75: 513-527.

Joshi SK, Dhstms BD, Bhatia CR, Singh RV, Thakur RS 1992. The wealth of India raw materials Vol. III, New Delhi; Council of Scientific Industrial Research p. 270-271. 
Khandelwal KR 2007. Practical Pharmacognosy Techniques and Experiments. $18^{\text {th }}$ edition Nirali Prakashan. Pune, p. $149-150$.

Krall RL, Penry JK, White BG, Kupferberg HJ, Swinyard EA 1978. Antiepileptic drug development: II Anticonvulsant drug screening. Epilepsia 19: 409-428.

Leewanich P, Tohda M, Matsumoto K, Subhadirsakul S, Takayama H, Watanabe H 1996. Behavioural studies on alkaloids extracts from the leaves of Hunteria zeylanica. Bio Pharm Bull 19: 394-399.

Liow K, Barkley, GL, Pollard JR, Harden CL, Brazil CV 2007. Position statement on the coverage of anticonvulsant drugs for the treatment of epilepsy. Neurology 68: 12491250 .

Loscher W, Schmidt D 1988. Which animal models should be used in the search for new antiepileptic drugs? A proposal based on experimental and clinical considerations. Epilepsy Res 2: 145-181.

Madepalli K, Lakshmana, Raju TR 1997. An isocratic assay for norepinephrine, dopamine, and 5-hydroxytryptamine using their native fluorescence by high-performance liquid chromatography with fluorescence detection in discrete brain areas of rat. Anal Biochem 246: 166-170.

Mattson RH 1992. Drug treatment of uncontrolled seizures. Epilepsy Res 5: 29-35.

MaynertEW, Klingman GI, KajiHK 1962. Tolerance to morphine. II. Lack of effects on brain 5-hydroxytryptamine and $\gamma$-aminobutyric acid. J Phar Exp Ther 135: 296-299.

Muthu C, Ayyanar M, Raja N, Ignacimuthu S 2006. Medicinal plants used by traditional healers in Kancheepuram District of Tamil Nadu, India. J Ethnobiol Ethnomed 2: 43-46.

Nag D 2000. Gender and epilepsy- A clinician's experience. Neurol Ind 48: 99-104.

Nassiri Asi, M, Zamansoltani F, Torabinejad B 2009. Antiepileptic of quinine in the entylenetetrazol model of seizure. Seizure 18: 129-132.

Organisation for Economic Co-operation and Development 2001. OECD guideline for testing of chemicals. http://www.epa.gov/oppfead1/harmonization/docs/ E425guideline.pdf. Acessed Jul 2009.

Rudiger K 2002. Voltage gated sodium channel in epilepsy. Epilepsia 43:1278-1296.

Sheeba MS, Asha VV 2009. Cardiospermum halicacabum ethanol extract inhibits LPS induced COX-2, TNF- $\alpha$ and iNOS expression, which is mediated by NF-қB regulation, in RAW264.7 cells. J Ethnopharmacol 124: $39-44$.

Subramanyam R, Newmaster SG, Paliyath G, Newmaster CB 2007. Exploring ethnobiological classifications for novel alternative medicine: a case study of Cardiospermum halicacabum L. (Modakathon, Balloon Vine) as a traditional herb for treating rheumatoid arthritis. Ethnobotany 19: 1-16

Sun XY, Jin YZ, Li FN, Li G, Chai KY, Quan ZS 2006. Synthesis of 8-alkoxy-4,5-dihydro-[1,2,4]triazole[4,3-a] quinoline-1-ones and evaluation of their anticonvulsant properties. Arch Pharm Res 29: 1080-1085.

Sun XY, Zhang L, Wei CX, Piao HR, Quan ZS 2009. Characterization of the anticonvulsant activity of doxepin in various experimental seizure models in mice Pharmacol Rep 61: 245-261.

Vaidhya ADB 1997. Status and scope of Indian medicinal plants on Central Nervous System. Indian J Pharmacol 29: 5340-5353.

Venkteshbabu KC, Krishnakumari S 2006. Cardiospermum halicacabum suppress the production of TNF-alpha nitric oxide by human peripheral blood mononuclear cells. Afr J Biomed Res 9: 95-99.

Vogels HG 2008. Drug Discovery and evaluation: Pharmacological assays, $3^{\text {rd }}$ ed. Springer New York. p. 693-695.

Wamil AW, Schmutz M, Portet C, Feldmann KF, McLean MJ 1994. Effects of oxcarbazepine and 10hydroxycarbamazepine on action potential firing and generalized seizures. Eur J Pharmacol 271: 301-308.

White HS 1999. Comparative anticonvulsant and mechanistic profile of the established and newer antiepileptic drugs. Epilepsia 40: S2-S10.

\section{*Correspondence}

\section{K. Nandakumar}

Department of Pharmacology, Manipal College of Pharmaceutical Sciences, Manipal University

Manipal-576104, Karnataka, India

nandakumar77@rediffmail.com

Tel.: +91-9449951422

Fax: $+91-820-2571998$ 